\title{
The Magnificent Pilgrimage Route of Borobudur
}

\author{
Dirga Imam Gozali Sumantri ${ }^{\text {a, *, Muhamad Raihan }}{ }^{\mathrm{b}}$, Pindi Setiawan ${ }^{\mathrm{c}}$, Agung Budi Harto ${ }^{\mathrm{a}}$ \\ ${ }^{a}$ Research Group of Remote Sensing and GIS-Bandung Institute of Technology, Indonesia, dirgasumantr@itb.ac.id, \\ abh@gd.itb.ac.id \\ ${ }^{b}$ Geospatial Creative Institute, Indonesia, madraihan@gmail.com \\ ${ }^{c}$ Division of Visual Communication and Multimedia-Bandung Institute of Technology, Indonesia, pindi@fsrd.itb.ac.id \\ * Corresponding author
}

Keywords: Thematic maps, Borobudur, Pilgrimage, History

\begin{abstract}
:
The historical map of Magnificent Pilgrimage Route of Borobudur is the research product of history, cartography, and visual communication. The purpose is to reconstruct the information of ancient pilgrimage routes in the magnificent era of Borobudur temple in Java Island.

The pilgrim routes are considered from several factors. First, transportation images factor which is appeared in Borobudur Temple Relief. These images reflect many vehicles in the Buddhist era. There are many types of transportation such as land transportation, river transportation, and sea transportation. The transportation types image drawn on relief are assumed to fit into the technology achievement at that time and associated with the transfer of pilgrims by sea, land, and river comfortably and without harm.
\end{abstract}

Second, the route factors are considered from the transportation technology which connected with trading shipping routes. The story begins from the seafarers and pilgrims through South East Asia. Smooth seas along North Java construct the trading route and ports were being the gate of the island. Ashore, the territories of ruling kingdoms consider the chosen route.

Last, topographic and waterway conditions create optional routes to reach Borobudur. Topographic and waterway are generated with the current condition and combined with historical pieces of evidence. Shreds of evidence are collected from many scholars, maps, artefacts, and sites which related to peoples and goods movement.

Mainframe focusing on the landscape perspective of the temple. Side information points out the entire journey with smallscale maps, figures, and infographics. Reliefs and characters of Borobudur are used to enrich the element of the map. The product will be drawn on a printed map. 